\title{
Formation of a quasi-professional environment in the training of chiefs of units of departments for educational work with convicts of correctional institutions in educational institutions of higher education of the Federal Penitentiary Service of Russia
}

\author{
Elena Khrabrova ${ }^{1,{ }^{*}, \text { Marina } \text { Cherkasova }}{ }^{1}$, and Evgenia Chernyshenko ${ }^{1}$ \\ ${ }^{1}$ Vologda Institute of Lawand Economics of the Federal Penitentiary Service of Russia, Vologda, \\ Russia
}

\begin{abstract}
The article considers the features of the organization of quasiprofessional environment in the training of chiefs of units of departments for educational work with convicts, defines the mission statement of its creation in higher education institutions of the Federal penitentiary service. The most successful forms of organization of quasi-professional activities of students are also studied in detail, and the analysis of data testifying to the quality of training of specialists for the Russian Penal System by the Vologda Institute of Law and Economics of the Federal penitentiary service at the moment is carried out. The article draws conclusions about the most promising areas of development of the process of organizing a quasi-professional environment for training student of departmental institutions of the Russian penal system.
\end{abstract}

\section{Introduction}

Training of chiefs of units of departments for educational work with convicts (hereinafter DEWC) of correctional institutions by educational organizations of the Federal Penitentiary Service of Russia is currently carried out in accordance with the competence paradigm. The Federal state educational standard of higher education in the specialty 40.05.02 Law enforcement (specialist level) defines the list of competencies that a specialist should have based on the results of mastering the educational program $[1,2]$. Training of specialists in the higher education system has a practice-oriented approach, which involves the formation of required skills and further successful integration of the graduate of an educational organization into professional activities[3, 4, 5, 6].

The chief of unit of DEWC is a difficult position from the point of view of functional duties, due to the fact that it obliges the specialist to show quite versatile abilities: organizational, analytical, standard-setting, pedagogical, psychological, etc. [7]. The

\footnotetext{
${ }^{*}$ Corresponding author: khrabrova-elena@yandex.ru
} 
formation of a specialist with such qualities implies the need to create conditions in the educational process that model the future professional activity, which will allow to prepare a specialist who is able to perform the tasks set.

Annually, the educational organization of the Federal Penitentiary Service of Russia carried out a study of the quality of training their graduates through a survey, both of themselves and their immediate supervisors, in whose obedience they fall, coming to the service in institutions and agencies of Penal Enforcement System. The results of these surveys allow us to determine whether the training strategy chosen by educational organizations corresponds to the request of the founder (employer). The results of the research show, that the most popular qualities of trained specialists include: the ability to organize a team, communication skills, knowledge of the requirements for drawing up official documentation, as well as the provisions of regulatory legal acts regulating the activities of institutions and bodies of the penal system, resistance to stress, literacy of oral and written speech, physical fitness. An important aspect in the training of specialists, respondents note the need for students to be involved in practical activities in the process of obtaining education.

\section{Methods}

To implement these requirements, educational organizations of higher education of the Federal Penitentiary Service of Russia are currently actively using contextual training in the training of specialists, including chiefs of units of departments for educational work with convicts. The concept of contextual learning in 1991 was developed and justified in his doctoral dissertation by A.A. Verbitsky [8].

The choice of the concept is determined by the characteristics of the age of students (1823 years). At this stage of life, social expectations are formed, a system of value orientations, interests, and ideals is developed, and a person becomes an active full-fledged member of society. This is a period of high social activity, a kind of completion of the processes of intellectual and social integration of a young person into the system of public relations. The University develops the qualities of a specialist that will be in demand in professional activities. As noted by V.I. Slobodchikov, questions of professional selfknowledge, namely, the purpose and essence of the profession, its cultural and social value, and professional norms are updated. The leading sphere of activity at this stage is work with the corresponding differentiation of professional roles [9].

One of the basic forms of students' activity in the context of contextual learning, A.A. Verbitsky defined quasi-professional activity that models the conditions, content and dynamics of production, and the relationships of people employed in it in the classroom and in the language of science. In his research, the scientist attributed business games and game forms of employment to the forms of quasi-professional activity. Later, with the development of this concept, we investigated the problems and pointed out such possible forms as designing, creating and solving cases, organizational and activity games, and research work of students [10]. The process of developing and searching for new forms for the implementation of quasi-professional activities of students in higher education institutions continues continuously.

However, the quasi-professional activity of students, in our opinion, cannot exist separately from other elements of the educational environment that create the necessary conditions for its successful implementation. In this regard, the theory of pedagogic has a term such as quasi-professional environment, under which V.V. Epaneshnikov understands a set of psychological and pedagogical conditions, forms, means and methods of training, focused on the development of a set of professional competencies through the quasiprofessional activity of the student [11]. As can be seen from the definition, the quasi- 
professional activity of students is only an element of the quasi-professional environment, although it is central. However, without providing a set of other structural parts of the environment, the existence of such activities is impossible. Therefore, when asking the question of creating conditions for ensuring the quasi-professional activity of future specialists, an educational organization should take into account the full range of necessary forces and means.

In our opinion, the components of a quasi-professional environment are: subject-space (specialized classrooms, workplace, etc.), material and technical (computers, software, etc.), technological (business game, field intensives, complex exercises, case studies, etc.), spiritual (professionally-oriented traditions, norms of behavior, attitudes, lifestyle), personal (teachers with experience in practical professional activities; participation of veterans of the penal system in working with students; training of teachers in practical bodies, etc.).

The Vologda Institute of Law and Economics of the Federal Penitentiary Service of Russia, as well as other departmental educational organizations of higher education, trains specialists for institutions and bodies of the penitentiary system, is guided by this concept.

It should be noted, that the Institute uses the whole set of forms of training and education, both traditional and innovative, in which knowledge has the context of future professional activity.

\section{Results}

The purpose of organizing a quasi-professional environment in the training of chiefs of units of departments for educational work with convicts is to form specialists who can successfully integrate into professional activities after graduation. This goal defines a number of tasks that are aimed at solving the formation of the environment:

- development of students' personal qualities;

- formation of competencies in accordance with the requirements of the Federal state educational standard of higher education qualification requirements established by the employer (founder);

- creation of conditions for active emotionally rich activity of students on assignment of practical experience, development of mental functions and abilities of the future specialist, system of intrapersonal and interpersonal relations.

\section{Discussion}

The chief of unit of departments for educational work with convicts performs the following official duties in a correctional institution:

- provides legal education to convicts, provides them with assistance in protecting their rights and legitimate interests;

- conducts individual educational work with convicts with different categories of convicts based on the study of their personal characteristics;

- warns and resolves conflict situations between convicts;

- deals with the prevention of violations of the established procedure for serving sentences, conducts interviews with violators;

- prepares various documents necessary for the implementation of the rights and obligations of convicts;

- rationally organizes the life activities of convicts (execution of daily routine by convicts, motivation to maintain a healthy lifestyle by convicts, inclusion of convicts in various types of useful activities); 
- contributes to improving the cultural and educational level of convicts (participation of convicts in group work, obtaining various levels of general and professional education, self-education of convicts, reading books, participating in competitions, intellectual competitions, sports competitions, festivals);

- organizes the preparation and conduct of educational, cultural, sports and other events with convicts [12].

In this regard, at present, the position of chief of unit of departments for educational work with convicts has quite high requirements. They must have such competencies, as organizing work in a group of convicts, interacting with other departments and services of the correctional institution, involving social institutions of civil society and public organizations in the education of convicts, conducting educational work with convicts (giving lectures, explaining, convincing, arguing, giving examples, etc.), correctly allocating their time, planning and analyzing work in the unit, predicting the behavior of convicts and preventing violations, and others [13].

Currently, DEWC employees implement an individual approach through the use of incentives and penalties, the implementation of the convict's right to early parole, transfer to a colony-settlement, etc., must be able to plan educational work, compile statistical reports on the results of their activities, for this, they must have knowledge of the current legislation regulating the procedure and conditions for the execution and serving of sentences by convicts in various types of correctional institutions, and the ability to act in accordance with the law, being guided by the principles of legality, make decisions and perform legal actions in strict accordance with the law, correctly draw up legal and official documents [14].

The chief of unit of departments for educational work with convicts has to receive and advise convicts on personal issues that most often relate to the civil law sphere: marriage, apartment sales, inheritance registration, alimony obligations, pensions, allowances, lumpsum payments, etc.

Higher education organizations of the Federal Penitentiary Service of Russia use various forms, methods, and tools to create a quasi-professional environment.

For example, the Vologda Institute of Law and Economics of the Federal Penitentiary Service of Russia has created working training places, in particular, the working training place of the chiefs of units of departments for educational work with convicts. It is intended to familiarize students with the order of record keeping and the conditions necessary for the effective and high-quality organization of the activities of the head of the correctional institution of the Federal penitentiary service of Russia, as well as the development of the relevant the Federal state educational standard of higher education in the specialty 40.05 .02 Law enforcement competencies.

The working training place of chiefs of units of departments for educational work with convicts is used primarily for studying the disciplines "Educational work with convicts", "Criminal Executive law", "Legal regulation and organization of the regime", " Security provision " and when conducting complex inter-departmental exercises with students of final courses. The materials available in the study are used for writing term papers, final qualification papers, conducting research by students, and writing articles.

At the workplace of chiefs of units of departments for educational work with convicts, there are a variety of methodological tools that equip and contribute to a more effective implementation of quasi-professional activities of students. In particular, information stands "Samples of official documents of chiefs of units of departments for educational work with convicts"; "Organization of work with the team of convicted prisoners"; "The Balance of power of the Council of educators group", "Structure of a correctional institution"; list and texts of legal documents regulating the activities of the head of the convict squad of the Federal Penitentiary Service of Russia; official documentation of the employee: samples of 
orders on activities, samples of job descriptions of the head of the correctional unit, samples of documents; materials for conducting classes (workshops, collections of tasks, guidelines, practical recommendations, methodological developments of classes, etc.); architectural model of the correctional institution.

Currently, all information about convicts in correctional institutions is accumulated and processed using the software package "Automated card index of special contingent of the correctional colony" (hereinafter - SP ACISC of CC) $[15,16]$. Accordingly, each chief of unit of departments for educational work with convicts must have the skills to work in the SP ACISC of CC. To solve this problem, the workplace is equipped with computers that have the necessary software installed.

One of the forms of organizing training in a quasi-professional environment is field practical training. It is organized to familiarize students with the features and content of professional activities of chief of unit of departments for educational work with convicts, development of best practices of educational work with convicts, and the formation of skills of carrying out educational work with convicts. When preparing for the field lesson, students use the theoretical knowledge obtained at lectures and seminars, select the most effective forms of work with convicts. The subject matter is determined by the purpose of correcting convicts, preparing them for life after release from a correctional facility, and improving their cultural and educational level. So, at one of the field sessions, students introduced women sentenced to imprisonment to the possibilities of electronic passports and electronic workbooks, which will soon be introduced everywhere. The second group of students spoke about the activities of search teams and expeditions that perpetuate the memory of those, who died during the Great Patriotic War. The third group organized an educational brain-ring game among the convicts, dedicated to women scientists, writers, poets and other outstanding women. The fourth group gave a lecture on healthy lifestyle and organized a class aimed at self-knowledge and self-understanding. Women sentenced to imprisonment were attracted by the conversation "Values of life", which was held in an interactive form.

After the field session, all students write a report, that they learned something new, what they learned, what disciplines they actively used, what knowledge they lacked, whether the educational event they conducted achieved their goals, and what conclusions they made. Then the results of the field session are discussed together.

As our experience shows, such classes contribute to the integration of theoretical knowledge and practice in solving professional problems, and contribute to the formation of professionally specialized competencies.

Field classes are held not only in correctional colonies. The management of the Institute signed an agreement on cooperation with a special educational institution for school students with deviant (socially dangerous) behavior. The purpose of the interaction is to help organize and conduct educational and preventive measures with school students aimed at correcting and preventing illegal actions and behavioral deviations.

In accordance with this purpose, students organize and conduct activities that are aimed at overcoming the consequences of school and social maladaptation of adolescents, correcting their developmental disorders, forming their conscious need for education, profession, leading a law-abiding lifestyle, the ability to self-esteem, self-control, making independent decisions in critical conditions, adaptation and self-realization in various spheres of public life.

Students implement individual, group and mass forms of educational work.

Examples of activities:

- brain-ring "The Own Game" - aimed at the intellectual development of adolescents, awareness of socio-psychological processes, training in tolerance skills, developing a desire to cooperate, working in a group; 
- "Merry starts" - sport event, which promotes the development of motor skills in adolescents, and the formation of universal educational actions, the will to win, ability to plan and organize the activities of the entire team, development of a sense of mutual support and friendly relations;

- "Military service" - event, suggesting a conversation (with a screening and discussion of excerpts from films and documentaries) about the importance for men of military service;

- conducting football, basketball and volleyball matches;

- quests aimed at developing athletic, intellectual and creative abilities of teenagers;

- sports relays, the purpose of which is to enable minor values of a healthy lifestyle;

- projects dedicated to the Victory day in the Great Patriotic War;

- guitar lessons, learning new pieces of music.

As practice has shown, sports events have the greatest success, which corresponds to adolescence, their psychological and physiological characteristics. They are aimed at unity, allow you to relieve tension, get positive emotions.

In addition, on the basis of this school, students carry out research activities in order to obtain empirical material for writing articles, term papers and other research; they study positive experience in organizing psychological, social and educational work with minors.

A field intensive of professional skills can be called the participation of students and "difficult teenagers" in the course of initial professional training at the suburban educational base of the Institute. For this event, the management of the school selects the most positively characterized children, who do not have comments and actively participate in school events.

During the week, at the suburban training base, young men learn to live according to the daily routine, move around as part of a unit, navigate the terrain, correctly put on gas masks and use special equipment. Classes in physical, fire, combat, psychological, legal and medical training are conducted by University teachers, psychologists, as well as officers of combat training units.

The purpose of this form of work is to consolidate the positive results of educational work, motivation for self-education, maintaining a healthy lifestyle, playing sports, and serving in the army. The students are role models for teenagers. At the same time, the value of a positive example in the upbringing of teenagers is great. Even K.D. Ushinsky wrote, that the educational power is poured out only from the living source of the human personality, that the education of the individual can only be influenced by the individual. An example provides concrete role models and thus actively forms consciousness, feelings, beliefs, and activates activity.

For students of Institute:

- the special educational institutions have extensive experience of working with teenagers with deviant behavior is psychological-medical-pedagogical rehabilitation of school children, has psychological-medical-pedagogical commission develops and implements tailored itineraries for the development and rehabilitation of adolescent, development programmes for groups of pupils, - all the students will be able to use in their future practical work;

- in the process of communication and interaction the students learn to see the personality and individuality of each pupil, to understand the causes of deviant behavior, which often caused by environmental factors (for example, a woman marries a man with whom the teenager had an awkward relationship, the woman in this situation chooses her husband, and the son remains unnecessary, is "on the street"; provided the parents are busy with career and a, the child is financially secure but does not feel love, he understands that he is "all is possible" is in "bad company"; the grandmother is raising her grandson, you can't implement all of his physical needs because of the small pensions for a teenager to 
earn money leads him to commit crimes; the uselessness and permissiveness of children in orphanages also end crimes, etc.);

- practice and master individual work: learning to establish contact with the teenager to determine the mood and other emotions, to diagnose, to talk, to motivate to participate in activities, find the approach to each, etc.;

- learn to plan and conduct various forms of educational and preventive work.

For school children:

- in the process of communicating with young people who are slightly older than them, they get experience of communicating with carriers of a prosocial subjective position, they perceive information better, in addition, the intellectual abilities of teenagers develop in an interesting way, and an attitude to a healthy lifestyle is formed;

- individual and group work carried out by students reduces the values of the criminal subculture, focuses on universal values;

- in the course of joint activities and events, a positive attitude is formed among teenagers to serve in the army and protect the motherland;

- students provide a positive example, since the interaction involves those who study well, participate in scientific work, are engaged in creativity, sports, have an active life position, that is, they are able to engage in interesting activities.

Complex exercises also represent a quasi-professional activity of students, since they model the conditions of professional activity, relationships of correctional officers, and recreate the subject, social, and psychological content of a specialist's work.

The purpose of complex exercises is to:

- consolidate the theoretical knowledge obtained by students in the process of mastering the educational program;

- formation and improvement of professional and professional-specialized competencies;

- development of professionally important qualities of an employee of the penitentiary system;

- assessment of the level of readiness of students for professional activities.

Tasks of complex exercises:

- application of theoretical knowledge in the field of order and conditions of execution of punishments connected with isolation condemned from society; the organization and conduct of educational work with convicts; peculiarities of educational work with various categories of prisoners; detection and investigation of penitentiary crimes, actions during emergencies; legal control and security and oversight;

- development of skills in working with regulatory legal documents, registration of necessary documents, materials for checking reports of a crime, work plans, lesson notes;

- formation of skills to work in a small team of correctional institution employees in various situations, including in emergency situations; to interact with employees of other departments, representatives of state bodies, public associations, etc.; to organize and conduct work in accordance with their official duties.

The exercises are held in several stages over six days. The first stage is aimed at studying (fixing) by students of normative documents on the organization of correctional colony activities, specific job descriptions in accordance with the distribution of roles in the game team, developing skills in planning regime and educational activities, as well as the correct execution of relevant documentation.

The main forms and methods of conducting classes: solving official tasks, working with official documents in the course of a business game.

The second stage is aimed at developing students' skills and abilities to use theoretical knowledge in the performance of official duties of the correctional facility's employees, as 
well as to exchange information and formulate the necessary points of view. In addition, at this stage, the level of knowledge, skills and abilities of students on the organization of correctional institutions, both in normal conditions and in conditions of complication of the operational situation, is evaluated. Classes are held in the form of a business game. The venue is the Institute's classrooms and a suburban training base.

The formation and development of professionally important qualities is facilitated by the involvement of veteran and active employees of the penitentiary system in the process of training and education of students. They conduct both individual conversations and group lectures, where they talk about their practical activities, the importance of the profession, share their methods and techniques of educational work with convicts, help overcome doubts and difficulties of the service.

Thanks to the creation of quasi-professional environment in the preparation of chiefs of units of departments for educational work with convicts, as the results of conducted annually by the Vologda Institute of Law and Economics of the Federal penal service of research training quality of the graduates, in recent years, the level of preparedness of graduates for professional activity has increased significantly. So, in 2016 , only $33,77 \%$ of employees of institutions and bodies of the Federal Penitentiary Service of Russia surveyed noted full readiness to perform their official duties by graduates of the Institute, in 2017 $46,53 \%$, and in 2018 and 2019, this figure was already $72,22 \%$ and $78,1 \%$, respectively.

The respondents also note a high level of formation of the following skills and abilities among graduates: the ability to correctly build oral and written speech (in $2019-65,6 \%$ of respondents), resistance to stress ( $71,9 \%$ of respondents), the ability to take responsibility for decisions made in official activities ( $100 \%$ of respondents), the level of development of moral qualities $(78,1 \%$ of respondents), the ability to observe and protect human and civil rights in the performance of official duties (59,4\% of respondents), the ability to prevent corrupt behavior $(78,1 \%$ respondents).

\section{Conclusion}

These data indicate the high efficiency of the training technologies used in training specialists in educational organizations of the Federal Penitentiary Service of Russia. The creation of a quasi-professional environment in the training of chiefs of units of departments for educational work with convicts of the Federal Penitentiary Service of Russia, the use of various forms of quasi-professional activities of students allows us to achieve the main purpose - the formation of specialists, who can integrate into professional activities after graduation, it is easier to overcome difficulties during service in institutions and bodies of the penitentiary system, and act effectively in changing conditions.

As promising areas of development, we see the need to introduce and develop new forms and methods of organizing quasi-professional activities of students, in particular, the Vologda Institute of Law and Economics of the Federal Penitentiary Service of Russia is working on the issue of creating training jobs on the basis of correctional institutions of the penitentiary system, where graduates will serve after graduation. Such forms will allow students to significantly expand their practical experience.

\section{References}

1. L.V. Orlova, Competence approach in the educational process of higher education institutions, Proceedings of the Samara scientific center of the Russian Academy of Sciences, 2, 41-44 (2011) 
2. G.A. Ragozina, I.V. Konyakhina, The value of the competence paradigm in education, Privolzhsky scientific Bulletin, 2 (30), 159-165 (2014)

3. M.M. Olesova, Application of practice-oriented learning technologies in higher education, Philological Sciences. Questions of theory and practice, 7-2 (773), 201-204 (2017)

4. I.V. Vyatkina, S.V. Vyugina, Opportunities to use innovative technologies in the educational process of the University, Proceedings of the international Symposium "Reliability and quality" 1, 247-288 (2018)

5. Yu.B. Leneva, O.I. Vaganova, J.V. Smirnova, Practice-oriented approach in professional education, Innovative Economics: prospects for development and improvement, 6 (32), 123-126 (2018)

6. L.I. Kutepova, O.I. Vaganova, E.I. Dvornikova, Technologies of contextual competence-based learning in vocational education, Innovative economy: prospects for development and improvement, 6 (32), 92-96 (2018)

7. A.N. Siryakov, Organization and conduct of educational work by the head of the detachment of convicts of a correctional institution, Human: crime and punishment, 1 (56), 46-49 (2007)

8. A.A. Verbitsky, Psychological and pedagogical foundations of contextual learning in higher education (abstract of the dis. doctor of pedagogical sciences: 13.00.01, 19.00.07, Moscow state pedagogical University, Moscow, 1991)

9. V.I. Slobodchikov, E.I. Isaev, Fundamentals of psychological anthropology. Psychology of human development: Development of subjective reality in ontogenesis (Moscow, 1995)

10. O.B. Dautova, Professional competence of the teacher-educator (St. Petersburg, 2005)

11. V.V. Epaneshnikov, Implementation of a quasi-professional educational environment in the professional training of school teachers, Kazan pedagogical journal, 4 (117), 7680 (2016)

12. Order of the Ministry of Justice of Russia dated 30.12.2005 № 259 (ed. from 15.08.2016) "On approval of The regulations on the detachment of convicts of the correctional institution of the Federal penitentiary service" (Rossiyskaya Gazeta, 2006)

13. M.V. Kiselev, S.B. Filimonov, N.N. Ivashko, O. V. Igumnova, S.A. Storozhev, Priority directions of the work of the heads of the detachments of convicts and the difficulties arising in the implementation of their functional duties, Bulletin of the Kuzbass Institute, 1, 173-183 (2015)

14. V. Novikov, Would you like to become a head of the prison squad?, Crime and Punishment, 4, 28-29 (2014).

15. A.A. Babkin, Automation tools for the service activities of chiefs of units of convicts (for example, using the SP ACISC of CC), Information and technical support of the activities of the penal system at the present stage, 3-6 (2017)

16. D.Yu. Kryukova, A.A. Babkin, Information support of the activities of the criminal executive system: problems of organization and improvement (Vologda, 2018) 